ISSN: 2162-3104 Print/ ISSN: 2166-3750 Online

Volume 8, Issue 4 (2018), pp. 1831-1847

(C) Journal of International Students

http://jistudents.org/

doi: $10.5281 /$ zenodo. 1468092

\title{
A Qualitative Exploration of On-Campus Experiences of English-Speaking Graduate International Students at a Leading Japanese University
}

\author{
Mahboubeh Rakhshandehroo \\ Osaka University, Japan
}

\begin{abstract}
With the rapid expansion of English-medium courses/degree programs at Japanese universities over the past 15 years, a greater number of English-speaking international students from diverse backgrounds are being attracted. However, little research has been conducted to address the needs of this minority group, especially at the graduate level. Employing interpretative phenomenological analysis (IPA), this study explores on-campus satisfaction with life (SWL) of nine graduate international students studying primarily in the Englishmedium regarding the support model of their Japanese university. Four master themes of traditional support, student ideal support, challenges, and best practices are discussed. The results present effective Japanese university support strategies that can promote SWL of English-medium graduate international students.
\end{abstract}

Keywords: university support, graduate international student, internationalization of higher education, Japan

In 2016, Japan was the third largest economy in the world with a GDP of \$4.949 trillion (World Bank, 2016). Given the attraction of Japanese culture, the country's safety record, and the strength of Japanese universities in the fields of engineering and science, in 2014, Japan ranked as the seventh most popular study destination for international students, attracting 3\% of all international students globally (UNESCO Institute for Statistics, 2016). However, in 2015, international students compromised $3.4 \%$ of tertiary students in Japan, which is below the average of 5.6\% amongst OECD countries (OECD, 2017). Furthermore, Japan fails to attract the majority of these students to enter its workforce. In 2015, it could only employ $30.1 \%$ of graduated international students (Japan Student Services Organization, 2017a).

As a result of Japan's low fertility rate, attracting international students to Japan's workforce is gaining importance. The recent Japanese government's internationalization initiatives have especially focused on attracting English-speaking graduate international students, who can contribute to building a better profile for Japan's leading universities in the heavily English-based international rankings as well as attracting them to Japan's workforce as highly-skilled professionals who would contribute to Japan's global competitiveness (Ishikawa, 2011). Yet a so-called Galapagos Syndrome (Garapagosu-ka), which refers to an inward- 
looking approach to Japan's export market, has caused challenges in the internationalization of Japanese industry and its foreign labor market. A similar conservative approach can be seen in the internationalization of the higher education (HE) sector (Hirasawa, 2009).

Over the past 15 years, the Japanese government as the main actor in the internationalization of Japanese HE has successfully increased the number of international students as well as English-medium instruction (EMI) courses and/or full-degree Englishtaught programs (ETPs). Nevertheless, it has been criticized for putting too much focus on the numeric targets with a project-based approach, in which less attention has been focused on preparation for increased diversity in order to support these international students from diverse backgrounds (Bradford, 2016; Bradford \& Brown, 2017; Brown, 2017; Hashimoto, 2013; Horie, 2002; Kuwamura, 2009; Tsuneyoshi, 2005). These government policy strategies and implementations from top-down perspectives have been addressed in an increasing number of scholarly studies. However, there is a shortage of literature from bottom-up standpoints, focusing on international students' experiences and their level of satisfaction (e.g., Shao, 2008), especially at the graduate level. Undergraduate international students have been the focus of the recent research since the majority of the Japanese universities are attracting undergraduate international students. This undergraduate-related body of research has largely focused on the students who are participating in EMI courses and/or full-degree ETPs (e.g., Bradford \& Brown, 2017). Furthermore, the research has largely focused on international students' selfadjustment, adapting procedure, and coping strategies (e.g., Lee, 2017). However, researching the university support system in relation to the students' needs has been neglected.

With an ongoing increase in the number of international students and the number of EMI courses and/or ETPs in Japanese universities, more students from diverse backgrounds are likely to be attracted to Japanese universities. These students are mostly non-native speakers of both Japanese and English and may come without sufficient Japanese language proficiency (Andrade, 2009; Kellem, 2014). At the graduate level, these students have to spend long hours at their laboratories for experiment and research, may have fewer opportunities to improve their Japanese language skills and to mingle with their surrounding Japanese community during their stay in Japan; thus, they may be in need of more English support, especially if they arrive with a low-level Japanese language proficiency (Rakhshandehroo, 2017).

This study contributes to the literature through a case study of a leading Japanese university and provides an Interpretive Phenomenological Analysis (IPA) of on-campus experiences of nine graduate international students regarding their perceptions of their satisfaction in relation to their Japanese host institution's on-campus support. The nine participants represent a minority group of the graduate international student population, who are coming to Japan to study primarily in the English-medium courses/programs, are from different backgrounds, and may need more English-language support. Although the majority of the international students in Japan are from Asia (93.3\%), many are from China (40\%), and are studying in the Japanesemedium, the number of English-speaking international students is increasing (JASSO, 2017b).

In this study, the following two main research questions are addressed: (1) What is the selfperception of English-speaking graduate international students regarding their on-campus satisfaction with life (SWL) experience in relation to their Japanese host university's support? What are the reasons they feel this way and how can they be best supported? (2) What, if any, are the associations between the students' linguistic and/or demographic backgrounds and their satisfaction regarding their university support? Do they have any special needs? 


\section{LITERATURE REVIEW}

During the 1980s, discourses of internationalization (kokusaika) gained prominence in Japanese higher education institutions (HEIs) (Aspinall, 2010; Goodman, 2007; Walker, 2005) due to the forces of globalization (gurōbaruka). Since then, international students have been one of the main targets of the internationalization of Japanese HEIs. Two recent initiatives have accelerated the flow of international students in Japan. In 1983, following Japan's economic recession, the Nakasone Plan was introduced with an aim to increase the number of international students as a response to demographic and economic forces including a declining population and more importantly to enhance Japan's soft power in the international community (Bradford, 2015; Haswell, 2014; Ishikawa, 2011). In 1983, the number of international students was 10,428 , and this plan aimed to recruit 100,000 international students by 2000 , a goal which was reached in 2003 (Goodman, 2007). Focusing on Japanese identity was one of the important parts of this plan, and it targeted the international students as temporary visitors who would leave Japan after their graduation.

This focus has gradually shifted to the quality of international students in order to secure the Japanese universities' position in the highly competitive international rankings (Haswell, 2014; Ishikawa, 2009; Lassegard, 2006). The Fukuda plan was introduced in 2008 when the number of international students was 123,829 . It aims to attract 300,000 international students to Japan by 2020 . The latest data show that the number is increasing rapidly: as of May 1 , 2017, there were 267,042 international students in Japan. However, this number includes longterm and short-term students (less than a year education in Japan), and compromises degree and non-degree programs: Japanese language institute students $(29.5 \%)$, university undergraduate students $(29 \%)$, professional training college students $(22 \%)$, university graduate students $(17.4 \%)$, and others $(2.1 \%)$ (JASSO, 2017b). This plan focuses on the global competitiveness of Japan and aims to cultivate global human resources (gurōbarujinzai) of its domestic students. Although this plan does construct international students as contributors to the Japanese workforce, the extent to which the Japanese community and universities are ready to accept these international students has been questioned (Rivers, 2010). Furthermore, the concept of gurōbaru jinzai has kept the idea of revitalizing Japanese identity by focusing on global competency. Thus, the concept has not sufficiently developed with a cosmopolitan focus to promote multiculturalism and global citizenship (Chapple, 2014; Wang, 2017).

In Japan's relatively monolingual and monocultural context, in which visible differences regarding race, ethnicity, and language, have long been grounded in the viewpoint of culture (Hirasawa, 2009), especially regarding physical appearance (Arudou, 2015), international students can be defined as foreign nationals enrolled in Japanese universities who are visibly different: non-native speakers, non-Japanese nationals, and on student visas. In this context, both of gurōbaruka and kokusaika are being seen as foreign elements, outside Japan (Burgess, 2012; Chapple, 2014). Aspinall (2010) discusses that the foreign elements are only being accepted if they are Japanized or being controlled for a temporary period.

Although this conflict between foreign elements and national characteristics is an ongoing challenge for many non-English-speaking developed countries (Hammond, 2016), in Japanese HE this conflict poses greater concerns as a result of Japan's long history of maintaining its homogenous background (Hirasawa, 2009). On the other hand, in Japan, the historical viewpoint that sees the English language as a foreign element (Fujimoto-Adamson, 2006; Hashimoto, 2013), and the traditional grammar-based teaching style of English, have caused challenges in the English communicative ability/desire of Japanese students and faculty (Koike 
\& Tanaka, 1995). Furthermore, the cultural concept of hazukashigaru (embarrassment) to speak English, even if they are fluent in English (Toh, 2016), can make the cultural integration of English-speaking international students even more challenging. This potentially puts the English-speaking international students at risk of isolation (Dejima-ization) (Bradford \& Brown, 2017; Burgess, Gibson, Klaphake, \& Selzer, 2010; Chapple, 2014; Shimauchi, 2018; Toh, 2016).

Among the 777 universities in Japan, only a few leading universities have received funding from the Ministry of Education, Culture, Sports, Science, and Technology (MEXT) that supports them to introduce and/or expand EMI courses and/or ETPs in order to encounter the Japanese language barrier, to increase diversity, and for better positioning of their HEIs in the competitive English-based rankings. These leading universities are mostly attracting graduate international students (Ota, 2014; Yonezawa, \& Yonezawa, 2016). The first important MEXT initiative was the Global 30 (G30) that funded 13 universities from 2009 to 2013. It aimed to facilitate the establishment of ETPs. The second one was the Go Global Japan Project, which funded 42 universities from 2012 to 2016, aiming at internationalizing domestic university students to foster their gurōbaru jinzai. The current initiative, Top Global University (TGU), targets 37 universities, focusing on the competitiveness of Japanese HE. This plan began in 2014 and plans to run until 2023 (Brown, 2014).

Although the majority of the international students are self-financed (95.1\%), MEXT's scholarship opportunities have been offered to a minority group of international students (3.4\%), who are more likely to come to Japan to study in the English medium. This scholarship does not require any Japanese language proficiency and aims to attract international students to Japan from diverse backgrounds (JASSO, 2017c).

There is no official data available to show the number of international students who are studying primarily in the English medium in Japanese HEIs, but the number of EMI/ETPs indicates that a minority group is studying in the English-medium (Shimauchi, 2018). The latest data from MEXT (2017, based on 2015 data) shows that in Japanese universities, EMI courses are being implemented more than full-degree ETPs, and full-degree ETPs provision have mainly focused on the graduate level: $29.4 \%$ of Japanese universities provide graduatelevel EMI, 39.2\% undergraduate EMI; $16.2 \%$ graduate ETPs, and 5.1\% undergraduate ETPs.

The position of graduate international students in Japanese leading universities has become more important under the government's Revitalization Strategy, introduced in 2013. The government is willing to attract international students to work in Japan as highly skilled workers in order to boost the country's global competitiveness (Hennings \& Mints, 2015; Ministry of Economy, Trade, and Industry, 2016). Despite these efforts, skilled workers ranked Japan as the last place in Asia where they would consider for work (Competitiveness Talent Rankings - IMD, 2017). In 2016, 51\% of international students reported that they do not want to work in Japan after their graduation (METI, 2016), with Japan's inflexible system as one of the main reasons for their decisions (Smith, 2017).

Despite the government's recent efforts, an inward-looking approach to the internationalization of $\mathrm{HE}$ has developed diverse meanings for kokusaika, turned it into a buzzword (Aspinall, 2010; Goodman, 2007), and may be harmful for Japan's long-term internationalization goals (Aspinall, 2010; Burgess, 2012; Hammond, 2016; Ishikawa, 2011). Although there were a few successful examples of English-speaking international student on-campus support (e.g., Ishikura, 2015), many researchers have reported on a call for the government and the universities to redefine kokusaika along global lines, and to provide a better support environment for the international students and faculty (Bradford, 2016; Bradford 
\& Brown, 2017; Brown, 2017; Goodman, 2007; Hashimoto, 2013; Heigham, 2014; Horie, 2002; Kuwamura, 2009; Tsuneyoshi, 2005; Walker, 2005).

\section{RESEARCH METHOD}

\section{Conceptual Framework}

Two important previous studies have guided this study. Firstly, Ishikawa's (2011) work is the only study that has critically examined the Japanese university's international student support to date. Her study shows that the Japanese university support focus is gradually being shifted towards providing a "global competitiveness" model in order to make the students autonomous by providing a suitable bilingual academic environment based on the students' needs. However, she points out that the support model in the Japanese universities, especially at leading universities, has been largely on the traditional "paternalism" model which means seeing international students as children, and supporting them with collective responsibility.

Secondly, Sam's (2001) satisfaction with life (SWL) model for international students is implemented in the current study. This approach was chosen since it has exclusively examined different areas of the student's satisfaction, with a focus on their lived (individual) experiences. SWL "has been defined as the global evaluation of a person's quality of life, based on the person's own chosen criteria" (Shin \& Johnson, 1978, cited in Sam, 2001, p. 316). Sam (2001) identifies seven SWL areas regarding students' university life satisfaction: "demographic characteristics, language proficiency, financial situation, academic situation, social activities, social relationships, and information received" (Sam, 2001, p. 318). Sam's (2001) study shows that international students with less than a year of study abroad experience tend to positively evaluate their SWL; however, they tend to evaluate their SWL more critically with gaining more experience. The study also highlights the positive influence of international students' linguistic proficiency in their host country's language. It shows that students from greater cultural distance backgrounds compared to their study destination's culture tend to face more difficulties in their social activities and social life. It highlighted the importance of creating sufficient interaction spaces for international and domestic students, since making friends with the host country students can be the least common type of friendship, due to the linguistic and cultural barriers.

The present study takes an interpretative, phenomenological, contextual constructivism approach to explore graduate international students' SWL regarding the on-campus support they receive from their Japanese university. It applies an explanatory narrative case study (Eisenhardt, 1989) "to render an accounting via narrative" (Sandelowski, 1991, p. 163) of why the satisfaction and/or dissatisfaction took place. Since the author is an international graduate student studying in the English-medium at a Japanese leading university, for in-depth understanding of the research questions, Interpretive Phenomenological Analysis (IPA) was used to analyse the data (Smith \& Osborn, 2003) through a double hermeneutics process, which involves co-constructing the participants' and the researcher's interpretations (Wojnar \& Swanson, 2007), and the reflexivity of the researcher throughout the research process (Flood, 2010).

\section{Methodology and Case Study Participants}

Prior to the start of the data collection, the ethical review process was completed at the author's university, and the ethical review was obtained from the research ethics committee of 
Kyosei studies in the Graduate School of Human Sciences at Osaka University (\#OUKS1628). Purposive sampling techniques were used for the selection of study participants based on the research purposes. This sampling method does not seek to produce generalizable results; rather, it focuses on the depth of the collected narrative data (Teddlie \& Yu, 2007). Nine international graduate students were recruited by voluntary participation. They were chosen as a relatively homogenous group (Smith, Flowers, \& Larkin, 2009), who are studying primarily in the English-medium and may be in need of more support because of language segregation. The nine participants were chosen from three main majors (humanities and social sciences, science, engineering), and different geographical backgrounds to explore the students' experiences in different settings at a deep level through IPA.

Their host university is a leading national Japanese university receiving TGU funding and is implementing full-degree ETPs mostly at the graduate level at more than five graduate schools. It hosts approximately 1,000 international graduate students primarily in the engineering and science majors. Unfortunately, there are no official data to show how many of these international graduate students are studying primarily in the English-medium. However, the number and size of this institution's graduate ETPs show that no more than 300 of these students are enrolled in ETPs. These ETPs have been designed to provide an all-English environment for international graduate students in which (according to the target university's official website) the students can study and graduate in the English-only medium.

Semi-structured, in-depth interviews were conducted with nine international graduate students between April and July 2017. Participants' names were anonymized and kept strictly confidential. interviews were face-to-face, each took between 30 to 90 minutes, and were conducted mostly in English, with some usage of Japanese based on the participants' preferences. Two interviews (Table 1, Olivia and Emma) were conducted primarily in a Middle Eastern language based on the interviewees' preference, with some usage of English. All of the interviews were transcribed, the non-English segments were translated into English, and transcriptions were coded. Emergent themes and subordinate themes were identified after a number of careful screenings of the interview transcriptions and the authors' explanatory notes that were written during and after the interviews (Smith et al., 2009).

\section{FINDINGS}

Table 1 presents the participants' demographic backgrounds, their self-perception of their linguistic abilities, and desire to stay in Japan after graduation. The participants were mostly PhD students, and many came to Japan prepared to study in the English-medium, with low-level Japanese proficiency. Amy and Emma (culturally) and Jack (linguistically) reported very challenging experiences; however, the rest of the participants were satisfied with their university's overall support. Many reported a desire to stay in Japan after their graduation due to Japan's safety and its economic status in Asia. Nevertheless, all of the participants identified challenging areas that could be improved to provide a better support network for international graduate students.

\section{Demographic Characteristics}


In terms of gender and age, there was no SWL impact. However, the length of sojourn in Japan had an influence on the students' satisfaction to a great extent. The participants with less

Table 1. Participants' demographic and linguistic backgrounds, and their desire to work in Japan after graduation.

\begin{tabular}{|c|c|c|c|c|c|c|c|c|}
\hline Pseudonym & $\begin{array}{l}\text { Time in } \\
\text { Japan }\end{array}$ & Region & $\begin{array}{c}\text { Receiving } \\
\text { MEXT } \\
\text { scholarship }\end{array}$ & Major & Gender & Age & $\begin{array}{c}\text { Self-perception of } \\
\text { linguistic background }\end{array}$ & $\begin{array}{l}\text { Desire to work in } \\
\text { Japan }\end{array}$ \\
\hline Thomas & $<1 \mathrm{yr}$ & Middle East & Yes & $\begin{array}{l}\text { Humanities \& Social } \\
\text { Sciences }(\mathrm{PhD})\end{array}$ & M & $25-30$ & $\begin{array}{c}\text { L2 E \& J; } \\
\text { native-level E, poor J }\end{array}$ & Agree \\
\hline Amy & $<1 \mathrm{yr}$ & North America & Yes & $\begin{array}{l}\text { Humanities \& Social } \\
\text { Sciences }(\mathrm{PhD})\end{array}$ & $\mathrm{F}$ & $31-35$ & $\begin{array}{c}\mathrm{L} 2 \mathrm{~J} ; \\
\text { native E, sufficient J }\end{array}$ & Agree \\
\hline David & $<1 \mathrm{yr}$ & North America & No & $\begin{array}{l}\text { Humanities \& Social } \\
\text { Sciences }(\mathrm{PhD})\end{array}$ & M & $31-35$ & $\begin{array}{l}\text { L2 speaker of J; } \\
\text { native } \mathrm{E} \text {, poor } \mathrm{J}\end{array}$ & Agree \\
\hline Daniel & $1-5 \mathrm{yr}$ & South America & Yes & Engineering $(\mathrm{PhD})$ & M & $25-30$ & $\begin{array}{c}\text { L2 E \& J; } \\
\text { sufficient E \& J }\end{array}$ & Undecided \\
\hline Jack & $1-5 \mathrm{yr}$ & Southeast Asia & $\mathrm{No}^{\mathrm{a}}$ & Engineering $(\mathrm{PhD})$ & M & $20-24$ & $\begin{array}{c}\text { L2 E \& J; } \\
\text { sufficient E, poor J }\end{array}$ & Undecided \\
\hline Noah & $1-5 \mathrm{yr}$ & Southeast Asia & Yes & Engineering (MA) & M & $20-24$ & $\begin{array}{c}\text { L2 E \& J; } \\
\text { sufficient E, poor J }\end{array}$ & Disagree \\
\hline Sophia & $<1 \mathrm{yr}$ & Southeast Asia & $\mathrm{No}^{\mathrm{b}}$ & Science $(\mathrm{PhD})$ & $\mathrm{F}$ & $25-30$ & $\begin{array}{c}\text { L2 E \& J; } \\
\text { sufficient E, poor J }\end{array}$ & $\begin{array}{l}\text { Disagree (scholarship } \\
\text { requirement) }\end{array}$ \\
\hline Olivia & $1-5 \mathrm{yr}$ & Middle East & Yes & Science $(\mathrm{PhD})$ & $\mathrm{F}$ & $25-30$ & $\begin{array}{c}\text { L2 E \& J; } \\
\text { native-level E, good J }\end{array}$ & Agree \\
\hline Emma & $1-5 \mathrm{yr}$ & Middle East & Yes & Science $(\mathrm{PhD})$ & $\mathrm{F}$ & $25-30$ & $\begin{array}{c}\text { L2 E \& J } \\
\text { native-level E, acceptable J }\end{array}$ & Undecided \\
\hline
\end{tabular}

than a year experience in Japan were more likely to positively evaluate their SWL and wanted to stay in Japan after graduation. However, when they have lived in Japan for more than a year, they tended to be more critical about their experience. In terms of the geographical origin of the participants, the visible difference was reported as a challenging area. Amy, Olivia, and Emma reported that their given identities were formed as a result of stereotypes based on their physical characteristics. For instance, Amy (North America) reported that her white-blond appearance had an impact on her feelings regarding social connectedness and her identity, which gave her an outsider and English-only-speaker identity. For instance, she explained that:

I think especially because I look like gaijin [non-Japanese], so they're [Japanese students/staff] really like oh this is white blond North American. That identity is very strong and the benefits and negative parts are very strong....this pushes me into the English gaijin bubble. So that definitely feels like giving me an identity I don't want...I had this one case that really made me feel like an outsider in my department. So, there was a party.... When they introduced me, they introduced me as an international student, and everybody else was like from a professor's lab. It just really felt like oh, I am an outsider. And then after that, everyone spoke to me in English even though I wanted to speak in Japanese. And when I spoke to them in Japanese it was like suddenly they didn't want to talk to me anymore. (Amy)

This issue is more significant in the case of Emma and Olivia (Middle East) since they had very similar backgrounds; however, they reported different SWL levels as a result of their visible physical characteristics. Olivia pointed out that she is usually being identified with an American identity because of her appearance, whereas Emma was viewed in terms of a Middle Eastern identity, due to her skin color and head-covering. Emma felt that the Middle Eastern identity has given her a strong outsider identity: 
If you are kawaii [cute], Japanese people will make friends with you easier. For example, maybe they have some negative images about my country, but when they see me as a kawaii individual, they may pay more attention to me compared to another individual from my country who is not physically attractive. (Olivia)

I feel like here [at her Japanese university], because of my head-covering, I have a strong Middle Eastern identity. I feel like I am a too foreign foreigner! (Emma)

\section{Language Proficiency}

Participants' self-perception of proficiency in English was adequate. However, many came with limited Japanese language knowledge. Amy and Olivia had better Japanese proficiencies and reported that this put them in a more advantageous position, especially because most of the administrative infrastructure is monolingual (Japanese), and some administrative staff, especially in the humanities and social sciences, provide monolingual support. Amy described her advantageous position due to her Japanese language proficiency as follows:

\section{I feel like I'm very lucky because I can speak Japanese. I think if I didn't speak Japanese, I would be frustrated all the time... a lot of the staff seem very resistant to communicate in English with international students. (Amy)}

Although MEXT (Japanese government) scholarship students, which include most of this study's participants, usually take a Japanese intensive course for one or two semesters when they arrive, this intensive course was reported to be not sufficient, especially regarding Japanese reading and writing skills that require learning a large number of Chinese characters (kanji). Many study participants had limited Japanese knowledge and it was expected that they can study in the full-degree ETPs with no need to deal with the Japanese language on-campus. They reported the monolingual (Japanese) administrative infrastructure as a great challenge and reported on a need for more English language support, including bilingual information and emails. The participants, especially those majoring in engineering and science, reported that during their study time in Japan, their time for studying the Japanese language is very limited due to the long hours of research work at their laboratories.

\section{Financial Situation}

For this study's participants, scholarship opportunities, especially MEXT, was one of the major areas of interest. They had been awarded MEXT scholarship through Japan's embassy in their countries, prior to their arrival, and they were not required to have any Japanese language proficiency. Because of awarding this scholarship, many had no financial concerns.

\section{Academic Situation}

The administrative infrastructure was identified as the major SWL-related challenge. It was reported to be largely monolingual (Japanese), and more importantly, complicated (based on traditional Japanese bureaucracy) which includes a lot of paperwork and signatures, with a high level of precision to follow all the rules, as can be seen in the following extract:

I was asked to prepare a resume... and the resume was revised more than ten times. And the reason was that they wanted a 100 percent accurate and 
precise punctuations, comma, dot... this precision is sometimes hypersensitivity to precision. (Jack)

The support office staff were reported to be very supportive; however, the support clearly fits into Ishikawa's paternalism model. For example, the following extract shows this matter in the humanities and social sciences:

International support office staff are very nice and helpful but they don't speak English. There're so many administrative duties that have to happen in Japanese and they're kind of pain. But then we get this additional informal support that makes it much easier. So I mean really when you think about it from the administrative infrastructural operational standpoint, it would be just far more efficient, just to have everything bilingually, just to have everything in English and Japanese... because the structural pieces are not in place, the person who runs that office [international student support office, humanities and social sciences] is having to do so much small minor tasks...I've never filled out so many paper forms in my life....And not just filling out so many forms but the forms that I fill out, I have to sign five or six times. (David)

Although in engineering and science the support was evaluated to be more systematized, it stills fits into the paternalism model. This support mainly relies on the informal support of the supervisors. Without this informal support, the students may miss some of the important information. For instance, one student noted that:

Although it's not ideal to be in the need of using Japanese for many forms, there's always someone to help with the translation [her supervisor]. (Olivia)

Another challenge was related to the quality and quantity of the Japanese language learning classes provided for international graduate students. Although these classes are free, they are reported to be limited to specific places and times and are not highly engaged with daily Japanese issues:

They [Japanese language instructors] couldn't focus on the actual Japanese that we needed for our lives. I think the classes were inefficient. And unfortunately the timing and location were quite challenging, so I think to offer more [classes]... and offering night-time classes...like in [different campuses]...You know it's extra-curricular in that sense. So it's ok to have it outside of the normal timetable. (David)

The final challenge was related to the amount of English being used in the full degree ETPs, which was reported to be largely dependent on supervisors' informal support. This means that the students in the English-degree programs can conduct their research in English and write their dissertation in English. However, the classes and seminars that they take can be monolingual (Japanese), based on their supervisors' and their lab mates' English language proficiencies. This can have an impact on the quality of the English classes. For instance, Jack described it as follows: 
As for my graduate school, they provide English lectures but I should say the quality is not so good. So it really depends on the lectures. If the professor doesn't have study abroad experience the class is kind of disastrous. And they put Japanese phrases in their speech, which is very confusing for me. (Jack)

\section{Social Activities}

Social activities were reported to have a close relationship with students' linguistic skills (e.g., Amy). Furthermore, not only does cultural distance play a role in the students' social activities, but the visible physical characteristic of the students can be even more important in the students' achievements regarding their social activities. For instance, Olivia reported a satisfying experience regarding her social activities, while Emma reported a strong feeling of loneliness.

\section{Social Relationships}

It was reported that with the Japanese students' hazukashigaru and difficulty of verbal communication in English, making friends with Japanese peers was challenging. Furthermore, different aspects of lab culture were reported to be challenging. For example, the following extracts present two elements of lab culture: academic/daily life communication and drinking culture (nomikai). Talking about daily life issues is reported to happen at nomikai, and in the lab, communication is around academic issues, only when necessary:

They [Japanese peers] don't want to talk to me. I mean they try to talk if they don't have any other chance, like in case of an academic problem. About the daily life, they just don't talk about it. (Jack)

In the lab, people don't talk to each other...But then in the parties, suddenly they change and they switch their personalities. And then the day after, they switch back to the formality. I just don't get it...it's very stressful for me. Actually, because of that, I don't want to join any activities like lab trips or drinking outside with my lab mates. It's scary and honestly, I don't like the feeling.... When you open yourself to someone and then suddenly you switch back... and it feels so weird. (Noah)

Similar to Noah, the other participants reported that they have stopped attending some of the social events of their laboratories, which had led to a greater isolation of this group with the domestic students. The participants reported that their university can have an important role in organizing seminars and/or workshops to familiarize international students with different aspects of Japanese lab culture and to promote deep interactions between domestic and international students.

\section{Information Received}

This was a serious concern for all of the participants. Although they had expected to deal with the Japanese language in their daily life, they did not expect that they have to use much Japanese on-campus, and many of their supervisors had told them that they do not need to use Japanese on-campus. For example, Sophia, explained it as follows: 
Before coming here [Japan], I contacted my supervisor and he suggested me to learn Japanese. But he said it's ok in the lab and in the university to use English, and for social life, I should learn Japanese...but in the lab, most of the students cannot speak English...at the whole laboratory meetings, students give their presentations in Japanese and I cannot understand. (Sophia)

This misinformation posed greater challenges for Olivia and Emma. They both had to change their supervisors and their graduate schools when they arrived. This was because their supervisors told them that they can study in the English-medium. However, they actually had to first take the university entrance exam in Japanese, and they did not know that. Because of their MEXT scholarship, this was very stressful for them. If they could not find another supervisor in time, they were at the risk of losing their MEXT scholarships. Both said that they have seen cases like this, in which this misinformation about the Japanese language requirement had actually led to a loss of MEXT scholarship:

When I was accepted for monbusho [MEXT] scholarship, I got two letters of acceptance from university $A$, and university $B$ [her current institution]. However, prior to my final decision, the committee of the university $A$ informed me that they need a high Japanese level and my Japanese proficiency does not meet this requirement. I got a bit upset at that time, but now I think it was great that they informed me in advance. University $B$ didn't notify me about the Japanese language requirement, and when I came here, I got really shocked! (Olivia)

It seems that this misinformation is due to a lack of experience of supervisors regarding English-speaking international students. Some EMI courses and/or ETPs have been launched only recently, and many of the supervisors are supervising the English-speaking international students for the first time. Thus, they are not aware of the possible monolingual (Japanese) entrance examination and/or administrative infrastructure.

The following diagram illustrates the master themes and subordinate themes identified from the data.

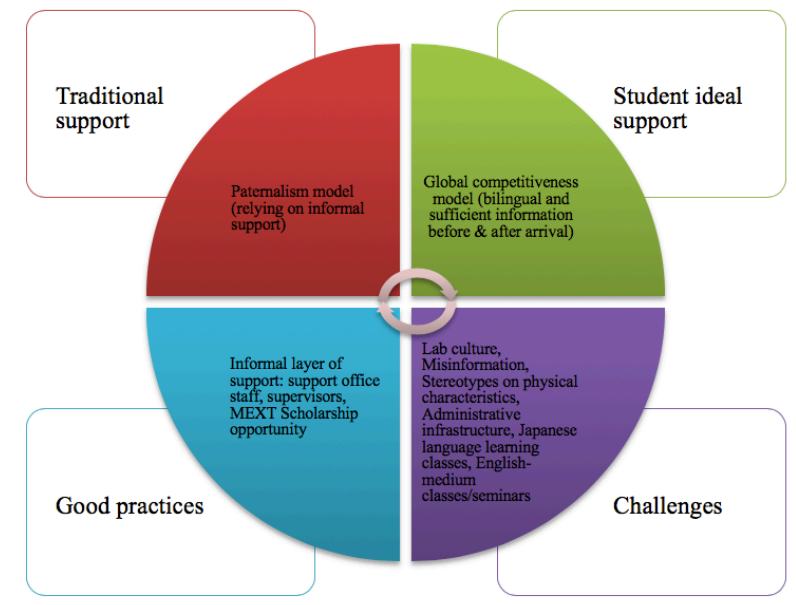

Figure 1. Master themes with subordinate themes. Note. The themes have emerged from the IPA of the study data 


\section{DISCUSSION AND CONCLUSIONS}

This article provides a qualitative phenomenological exploration of a minority group of international graduate students at a leading Japanese university. Although the majority of the international students in Japan come from Asia, study at the undergraduate level, are privately funded, and study in the Japanese medium, this minority group compromises students from diverse backgrounds who are mostly awarded a MEXT (Japanese government) scholarship and are studying in the English-medium at the graduate level. The numbers of this minority group have rapidly increased in Japanese HEIs due to a great increase in the number of EMI courses and/or full-degree ETPs over the past 15 years. Furthermore, this group of students is gaining more importance for Japanese HEI's English-based international rankings and Japan's global competitiveness. In the context of a shortage of research on the support needs of this minority group, this study provides an in-depth IPA of nine international graduate students studying in the English-medium at a Japanese leading university, aiming at exploring SWL (Sam, 2001) of the study participants in relation to their university's support model (Ishikawa, 2011).

The results showed that the MEXT (Japanese government) scholarship opportunity has successfully attracted these students who arrive with limited Japanese language proficiency, and it highlighted that despite the critical concerns regarding the definition of kokusaika in relation to the support of English-speaking international student in the literature (Bradford, 2016; Bradford \& Brown, 2017; Brown, 2017; Goodman, 2007; Hashimoto, 2013; Heigham, 2014; Horie, 2002; Kuwamura, 2009; Tsuneyoshi, 2005; Walker, 2005), the majority of this study's participants were satisfied with their host university's support, and many reported a desire to stay and work in Japan after graduation. However, the study participants indicated that the current support system can be improved.

The university support was reported to be largely fitting into Ishikawa's (2011) paternalism model by relying on the informal layer of support provided by supervisors and/or support office staff. Although in engineering and science, the support was reported to be in a transition phase towards a global competitiveness model by providing more bilingual information, announcements, and classes, compared to humanities and social sciences, it still fits into the paternalism model since this support largely relies on the informal support of the supervisors. In the humanities and social sciences, due to a shortage of English-speaking faculty and staff, the paternalism model was dominant. The participants reported different challenging areas in the current traditional support system that can be improved.

The main challenge was related to the largely monolingual (Japanese) administrative infrastructure, which is also reported to be relatively inflexible and complicated, relying on the Japanese form of bureaucracy. Another main challenging area was related to the information that the students have received prior to their arrival. Since many participants have been awarded a MEXT scholarship, which does not require any Japanese language proficiency, many had arrived with little Japanese knowledge. They came prepared to study in the Englishmedium, and many had expected to encounter a relatively English-only, on-campus environment. However, they had faced the barrier of Japanese language on-campus, especially for announcements, emails and information, and sometimes lab-based seminars. Moreover, the amount of English being used in the ETPs has been reported to be dependent on the informal support of the supervisors.

The results suggest that students' ideal support would consist of providing sufficient and bilingual information, before and after the students' arrival. Especially for MEXT students that 
are being awarded this scholarship before their arrival, sufficient information regarding the exact usage of English and/or Japanese on-campus was reported to be needed. Therefore, MEXT students can prepare themselves in advance. Moreover, at the graduate level, many of the participants had to spend long hours at their laboratories for their experiments and research. Especially students majoring in engineering and/or science had very limited time to spend on improving their Japanese language during their stay in Japan. Thus, this group of students is in need of more support, including more bilingual administrative infrastructure, English-medium classes and/or seminars, and extracurricular Japanese language learning classes.

These points show that the current paternalism model has successfully satisfied the majority of the study participants; however, moving towards a global competitiveness model fits into the student ideal support. Furthermore, with the government's continuous efforts to increase the number of ETPs at Japanese universities, more English-speaking international students are likely to be attracted. With a larger group of English-speaking students, providing the traditional paternalism support would waste much time and energy, and informal support might not fulfill the needs of the growing number of English-speaking students in the future.

Similar to Sam's (2001) study, the participants with less than a year experience in Japan and/or with better Japanese language proficiencies were more likely to positively evaluate their SWL and wanted to stay in Japan after graduation. This also highlights the importance of providing sufficient bilingual information to the students before and after their arrival, especially for the students who arrive with limited Japanese proficiency. In terms of the geographical origin of the participants, Hirasawa's (2009) visible difference was reported as a challenging area. Visible difference discourse was found to be influential in the students' feelings of on-campus SWL. It was reported that more strategic planning is required to provide deeper interaction spaces for domestic and international students, such as multicultural workshops, regarding raising awareness about stereotypes based on physical characteristics. Considering some Japanese students' hazukashigaru (embarrassment) to speak English, and/or linguistic limitations in terms of verbal communication, such workshops can have an important impact on promoting multiculturalism. These workshops can also be beneficial in raising awareness regarding Japanese lab culture and Japanese bureaucracy.

This study had several limitations. It only focuses on the international student perspective, thus, excluded the Japanese viewpoints of Japanese students, administrators, and professors. Furthermore, as a case study, to explore the research questions at a deep level, it only focused on the on-campus SWL of a homogenous group of the international graduate student (who are studying in the English-medium), in relation to their Japanese host university's support system. Although IPA of the current sample size (nine participants) does not enable generalizability of the findings, the in-depth analysis presented here provides a clear picture of the possible support needs of English-speaking international graduate students at leading Japanese universities. With the ongoing rapid increase of the number of international students and English-medium programs in Japanese universities, more research will be required to address the needs of different groups of international students, alongside the real implications of kokusaika strategies from bottom-up perspectives.

\section{REFERENCES}

Andrade, M. (2009). Increasing accountability: Faculty perspectives on the English language competence of nonnative English speakers. Journal of Studies in International Education, 14(3), 221-239. doi: $10.1177 / 1028315308331295$ 
Arudou, D. (2015). Embedded racism: Japan's visible minorities and racial discrimination. Lanham: Lexington Books.

Aspinall, R.W. (2010). Education reform in Japan in an era of internationalization and risk. Center for Risk Research (CRR), Shiga University, A-3, 1-20. Retrieved from http://libdspace.biwako.shiga-u.ac.jp/dspace/handle/10441/8890

Bradford, A. (2015). Internationalization policy at the genba: Exploring the implementation of social science English-taught undergraduate degree programs in three Japanese universities (Doctoral dissertation). Retrieved from ProQuest, UMI Dissertations Publishing. (3687531)

Bradford, A. (2016). Toward a typology of implementation challenges facing English-medium instruction in higher education: Evidence from Japan. Journal of Studies in International Education, 20(4), 339-356. doi: 10.1177/1028315316647165

Bradford, A., \& Brown, H. (Eds.). (2017). English-medium instruction in Japanese higher education: Policy, challenges and outcomes. Bristol: Multilingual Matters.

Brown, H. (2014). Contextual factors driving the growth of undergraduate English-medium instruction programmes at universities in Japan. The Asian Journal of Applied Linguistics, 1(1), 50-63. Retrieved from https://www3.caes.hku.hk/ajal/index.php/ajal/article/view/18

Brown, H. (2017). Why and why now? Understanding the rapid rise of English-medium instruction in higher education in Japan. Journal of International Studies and Regional Development, 8, 1-16.

Burgess, C. (2012). Maintaining identities: Discourses of homogeneity in a rapidly globalizing Japan. electronic journal of contemporary japanese studies. Retrieved from http://www.japanesestudies.org.uk/articles/Burgess.html?pagewanted=all

Burgess, C., Gibson, I., Klaphake, J., \& Selzer, M. (2010). The 'Global 30' project and Japanese higher education reform: An example of a 'closing in' or an 'opening up'?. Globalisation, Societies and Education, 8(4), 461-475. doi: 10.1080/14767724.2010.537931

Chapple, J. (2014). "Global Jinzai," Japanese higher education, and the path to multiculturalism: Imperative, imposter, or immature?. In Shimizu K., Bradley W.S. (Eds.), Multiculturalism and conflict reconciliation in the Asia-Pacific (pp. 213-228). London: Palgrave Macmillan.

Competitiveness Talent Rankings - IMD. (2017). Retrieved from https://www.imd.org/wcc/worldcompetitiveness-center-rankings/talent-rankings-2017/

Eisenhardt, K. (1989). Building theories from case study research. Academy of Management Review, 14(4), 532-550. doi: 10.5465/amr.1989.4308385

Flood, A. (2010). Understanding phenomenology. Nurse Researcher, 17(2), 7-15.

Fujimoto-Adamson, N. (2006). Globalization and history of English education in Japan. Asian EFL Journal, 8(3), 269-282.

Goodman, R. (2007). The concept of kokusaika and Japanese educational reform. Globalisation, Societies and Education, 5(1), 71-87. doi: 10.1080/14767720601133413

Hammond, C.D. (2016). Internationalization, nationalism, and global competitiveness: A comparison of approaches to higher education in China and Japan. Asia Pacific Education Review, 17(4), 555566. doi: 10.1007/s12564-016-9459-0

Hashimoto, K. (2013). 'English-only', but not a medium-of-instruction policy: The Japanese way of internationalising education for both domestic and overseas students. Current Issues in Language Planning, 14(1), 16-33. doi: 10.1080/14664208.2013.789956

Haswell, C. (2014). Asian students of English at an international university in Japan: A study of attitudes to the use and study of English (Doctoral dissertation). Retrieved from http://etheses.whiterose.ac.uk/7430/

Heigham, J. (2014). Voices on campus: International students in an English-medium instruction degree program in Japan. Journal of the Ochanomizu University English Society, 5, 64-74.

Hendrickson, B., Rosen, D., \& Aune, R. K. (2011). An analysis of friendship networks, social connectedness, homesickness, and satisfaction levels of international students. International Journal of Intercultural Relations, 35(3), 281-295. doi: 10.1016/j.ijintrel.2010.08.001 
Hennings, M. \& Mintz, S. (2015). Japan's measures to attract international students and the impact of student mobility on the labor market. Journal of International and Advanced Japanese Studies, 7, 241-251. Retrieved from http://japan.tsukuba.ac.jp/research/

Himeda, K. (2017). Easier permanent residency for highly skilled foreign professionals-Is Japan ready?. Retrieved from https://www.nippon.com/en/currents/d00304/

Hirasawa, Y. (2009). Multicultural education in Japan. In Banks, J. A., (Eds.), The Routledge international companion to multicultural education (pp.159-169). New York, NY: Routledge.

Horie, M. (2002). The internationalization of higher education in Japan in the 1990s: A reconsideration. Higher Education, 43(1), 65-84. doi: 10.1023/A:1012920215615

Howe, E.R. (2009). The internationalization of higher education in East Asia: A comparative ethnographic narrative of Japanese universities. Research in Comparative and International Education, 4(4), 384-392. doi: 10.2304/rcie.2009.4.4.384

Immigration Bureau of Japan. (2018). Points-based preferential immigration treatment for highly-skilled foreign professionals. Retrieved from http://www.immi-moj.go.jp/newimmiact_3/en/

Ishikawa, M. (2009). University rankings, global models, and emerging hegemony: Critical analysis from Japan. Journal of Studies in International Education, 13(2), 159-173. doi: $10.1177 / 1028315308330853$

Ishikawa, M. (2011). Redefining internationalization in higher education: Global 30 and the making of global universities in Japan. In Willis, D. \& Rappleye, J. (Eds.), Reimagining Japanese education: Borders, transfers, circulations, and the comparative (pp. 193-223). Oxford: Symposium Books.

Ishikura, Y. (2015). Realizing internationalization at home through English-medium courses at a Japanese university: Strategies to maximize student learning. Higher Learning Research Communications, 5(1), 11.

Iwabuchi, K. (2005). Multinationalizing the multicultural: The commodification of 'ordinary foreign residents' in a Japanese TV talk show. Japanese Studies, 25(2), 103-118. doi: $10.1080 / 10371390500225987$

Japan Student Services Organization (JASSO). (2017a). Japan Alumni eNews (Vol.98). Retrieved from https://www.jasso.go.jp/en/study_j/enews/enews_98.html

JASSO. (2017b). Result of an annual survey of international students in Japan 2017. Retrieved from https://www.jasso.go.jp/en/about/statistics/intl_student_e/2017/index.html

JASSO. (2017c). Trends in number of international students by source of funds. Retrieved from https://www.jasso.go.jp/en/about/statistics/intl_student_e/2017/_icsFiles/afieldfile/2017/12/25/ data17_01_e.pdf

Kellem, H. (2014). Research in internationalisation of higher education: A brief overview. Kwansei Gakuin University International Studies Research, Departmental Bulletin Paper, 3(1), 69-75. Retrieved from http://hdl.handle.net/10236/12106

Koike, I., \& Tanaka, H. (1995). English in foreign language education policy in Japan: Toward the twenty-first century. World Englishes, 14(1), 13-25. doi: 10.1111/j.1467-971X.1995.tb00336.x

Kudo, K., \& Hashimoto, H. (2011). Internationalization of Japanese universities: Current status and future directions. In Marginson, S., Kaur, S., Sawir, E. (Eds.), Higher education in the AsiaPacific (pp. 343-359). Dordrecht: Springer.

Kuwamura, A. (2009). The challenges of increasing capacity and diversity in Japanese higher education through proactive recruitment strategies. Journal of Studies in International Education, 13(2), 189-202. doi: $10.1177 / 1028315308331102$

Lassegard, J. (2006). International student quality and Japanese higher education reform. Journal of Studies in International Education, 10(2), 119-140. doi: 10.1177/1028315305283878

Lee, J. S. (2017). Challenges of international students in a Japanese university: Ethnographic perspectives. Journal of International Students, 7(1), 73-93. 
Ninomiya, A., Knight, J. \& Watanabe, A. (2009). The past, present, and future of internationalization in Japan. Journal of Studies in International Education, 13(2), 117-124. doi:10.1177/1028315308331095

Ministry of Economy, Trade and Industry (METI). (2016). 'Uchinaru kokusaika' kenkyū, gaiyō Hōkokusho. [Research Group for Domestic Internationalization Report]. Tokyo: METI. Retrieved from http://www.meti.go.jp/press/2015/03/20160322001/20160322001.html

Ministry of Education, Culture, Sports, Science and Technology (MEXT). (2017). Heisei 27 nendo no daigaku ni okeru kyōiku naiyō-tō no kaikaku jōkyō ni tsuite [About the state of affairs regarding university reforms to education in 2015]. Retrieved from http://www.mext.go.jp/a_menu/koutou/daigaku/04052801/_icsFiles/afieldfile/2017/12/13/1398 426 1.pdf

OECD. (2017). Education at a glance 2017: OECD indicators. Retrieved from https://www.hm.ee/sites/default/files/eag2017_eng.pdf

Ogawa, S. (2016). The divergence of multicultural education between the US and Japan. Bulletin of Morioka University, 33, 1-14. Retrieved from https://morioka.repo.nii.ac.jp/

Ota, H. (2014). Japanese universities' strategic approach to internationalization: Accomplishments and challenges. In: Yonezawa A., Kitamura Y., Meerman A., Kuroda K. (Eds.), Emerging international dimensions in east Asian higher education. (pp. 227-252). Dordrecht: Springer.

Rakhshandehroo, M. (2017). EMI and internationalisation: The experiences of Iranian international students in Japanese universities. electronic journal of contemporary japanese studies, 17 (3). Retrieved from http://www.japanesestudies.org.uk/ejcjs/vol17/iss3/rakhshandehroo.html

Rivers, D. J. (2010). Ideologies of internationalisation and the treatment of diversity within Japanese higher education. Journal of Higher Education Policy and Management, 32(5), 441-454. doi: 10.1080/1360080X.2010.511117

Sam, D. L. (2001). Satisfaction with life among international students: An exploratory study. Social indicators research, 53(3), 315-337. doi: 10.1023/A:1007108614571

Sandelowski, M. (1991). Telling stories: Narrative approaches in qualitative research. Journal of nursing scholarship, 23(3), 161-166. doi: 10.1111/j.1547-5069.1991.tb00662.x

Shao, C.F. (2008, July). Japanese policies and international students in Japan. Paper presented at the 17th Biennial Conference of the Asian Studies Association of Australia, Melbourne. Retrieved from http://artsonline.monash.edu.au/mai/files/2012/07/chunfenshao.pdf

Shimauchi, S. (2018). English-Medium Instruction in the Internationalization of Higher Education in Japan: Rationales and Issues. Educational Studies in Japan: International Yearbook, 12, 77-90.

Smith, N. (2017). Japan wants immigrants. The feeling isn't mutual. Retrieved from https://www.bloomberg.com/view/articles/2017-11-30/japan-wants-immigrants-the-feeling-isnt-mutual

Smith, J.A. \& Osborn, M. (2003) Interpretative phenomenological analysis. In J.A. Smith (Eds.), Qualitative psychology: A practical guide to research methods. London: Sage.

Smith, J. A., Flowers, P., \& Larkin, M. (2009). Interpretative phenomenological analysis: Theory, method and research. Los Angeles, CA: SAGE.

The World bank. (2016). Retrieved from https://data.worldbank.org/country/japan

Teddlie, C., \& Yu, F. (2007). Mixed methods sampling: A typology with examples. Journal of mixed methods research, 1(1), 77-100. doi: 10.1177/2345678906292430

Toh, G. (2016). English as medium of instruction in Japanese higher education: Presumption, mirage or bluff? New York: Palgrave MacMillan.

Tsuneyoshi, R. (2005). Internationalization strategies in Japan: The dilemmas and possibilities of study abroad programs using English. Journal of Research in International Education, 4(1), 65-86. doi: $10.1177 / 1475240905050291$

UNESCO Institute of Statistics (UIS). (2016). Global flow of tertiary-level students. Retrieved from http://www.uis.unesco.org/Education/Pages/international-student-flow-viz.aspx 
Walker, P. (2005). Internationalising Japanese higher education: Reforming the system or re-positioning the product. In Eades, J., Goodman, R. \& Hada, Y. (Eds.), The 'big bang' in Japanese higher education (pp. 165-182). Melbourne: Trans Pacific Press.

Wang, M. (2017). A qualitative study of higher education policy and practice in fostering global human resources in Japanese higher education institutions (Doctoral dissertation). Retrieved from https://livrepository.liverpool.ac.uk/3007182/1/200935284_Apr2017.pdf

Wojnar, D. M., \& Swanson, K. M. (2007). Phenomenology an exploration. Journal of Holistic Nursing, 25(3), 172-180. doi: 10.1177/0898010106295172

Yonezawa, A., Akiba, H. \& Hirouchi, D. (2009). Japanese university leaders' perceptions of internationalization: The role of government in review and support. Journal of Studies in International Education, 13(2), 125-142. doi: 10.1177/1028315308330847

Yonezawa, Y. (2017). Internationalization Management in Japanese Universities: The Effects of Institutional Structures and Cultures. Journal of Studies in International Education, 21(4), 375390.

Yonezawa Y., \& Yonezawa A. (2016) Internationalization of higher education as a response to globalization: Japan's policy challenges since the 1980s. In Healy E., Arunachalam D., \& Mizukami T. (Eds.), Creating social cohesion in an interdependent world. (pp. 191-204). New York: Palgrave Macmillan.

MAHBOUBEH RAKHSHANDEHROO, MA, is a PhD Candidate in Critical Studies in Transformative Education, Osaka University's Graduate School of Human Sciences. Her major research interest lies in the area of graduate international student English-Medium Instruction (EMI) support at Japanese universities. Email: u892411e@ecs.osaka-u.ac.jp 